\title{
Evaluation of Safety and Outcomes of Endoscopic Retrograde Cholangiopancreatography in 1337 Patients at a Single Center
}

\author{
Endoskopik Retrograd Kolanjiopankreatografinin Sonuçları ve \\ Güvenilirliğinin Değerlendirilmesi: Tek Merkezin 1337 Hasta Sonuçları
}

\section{Ebru TARIKCI KILIC $\odot$, Resul KAHRAMAN $\odot$, Kamil OZDIL $\odot$}

Ethics Committee Approval: This study approved by the Health Sciences University, Umraniye Training and Research Hospital Ethic Committee for Clinical Studies, 23 April 2018, 2018/49. Conflict of interest: The authors declare that they have no conflict of interest. Funding: None.

Informed Consent: Not Applicable.
Cite as: Tarikci Kilic E, Kahraman R, Ozdil K. Evaluation of safety and outcomes of endoscopic retrograde cholangiopancreatography in 1337 patients at a single center. Medeniyet Med J. 2019;34:290-6.

\begin{abstract}
Objective: Endoscopic retrograde cholangiopancreatography (ERCP) is the gold standard treatment for pancreaticobiliary diseases. The aim of this study was to evaluate the safety and review the outcomes of our experience of ERCP over the past 4 years.

Method: The clinical records of patients aged 18-104 years who underwent ERCP at our gastroenterology clinic between 2014 and 2018 were included in the study. Data were acquired from the hospital archive system.

Results: A total of 1337 patients with a mean age of $60.58 \pm 17.96$ years. including 775 female, and 562 male cases were included in the study. The patients were in the age groups of 18-30 $(n=39), 30-65(n=694), 65-75(n=274), 75-85(n=258)$, and $>85(n=72)$ years. Among them, $28.27 \%$ were rated as ASA III-IV on the American Society of Anesthesiologists scale. Although biliary cannulation with standard sphincterotomy was successful in 1303 (97.45\%), patients it could not be performed in 34 (2.55\%). patients Precut papillotomy was performed in 27 (79.41\%) of 34 patients. Furthermore, no complication was observed in 1207 patients (90.27\%), whereas 96 patients (7.18\%) had minor and major procedure-related and anesthesia-related complications. The 30-day mortality rate was $1.64 \%(n=22)$.

Conclusion: We concluded that ERCP, which is currently performed entirely for therapeutic purposes, is safe and lifesaving, with high clinical success rates.
\end{abstract}

Keywords: ERCP, pancreaticobiliary diseases, outcomes, complications

öz

Amaç: Pankreatikobiliyer hastalıkların tedavisinde endoskopik retrograd kolanjio pankreatografi (ERCP) altın standarttır. Çalışmamızın amacı son dört yılda ERCP konusundaki deneyimimizi gözden geçirip, ERCP işleminin güvenilirliğini değerlendirmektir.

Yöntem: Çalışmamız, 2014-2018 yıllarında ERCP işlemine alınan 18-104 yaş arasındaki tüm hastaların kayıtlarının retrospektif olarak incelenmesiyle gerçekleştirilmiştir. Gerekli veriye hastanemiz arşiv sisteminden ulaşılmıştır.

Bulgular: Toplam 1337 hasta çalışmaya dahil edildi. 775'i kadın, 562'si erkek, ortalama yaş 60,58 17,96 idi. Hastaların 39'u 18-30 yaş, 694'ü 30-65 yaş, 274'ü 65-75 yaş, 258'i 75-85 yaş, 72 'si ise 85 yaş üstü idi. Hastaların 28.27\%'si Amerikan Anestezistler Derneğine göre (ASA) III-IV'dü. İşleme alınan hastaların 1303'ünde $(\% 97,45)$ standart sfinkteretomi başarılı iken 34 $(\% 2,55)$. hastada başarılı olunmadı Erken kesi papillotomi 34 hastanın 27'sinde $(\% 79,41)$ gerçekleştirildi. Hastaların 1207'sinde $(\% 90,27)$ hiçbir komplikasyon görülmezken, 96'sında $(\% 7,18)$ anestezi ve işlem ile ilişkili minor ve major komplikasyon görülmüştür. Otuz günlük mortalite oranı \%1,64 $(n=22)$ olarak bulunmuştur.

Sonuç: Tümüyle terapötik amaçlarla uygulanan ERCP'nin yüksek klinik başarıslyla güvenilir ve hayat kurtarıcı olduğu kanaatindeyiz.

Anahtar kelimeler: ERCP, pankreatobiliyer hastalıklar, sonuçlar, komplikasyonlar

(c) Copyright Istanbul Medeniyet University Faculty of Medicine. This journal is published by Logos Medical Publishing.

Licenced by Creative Commons Attribution-NonCommercial 4.0 International (CC BY-NC 4.0)
Received: 4 April 2019

Accepted: 15 June 2019 Online First: 27 September 2019

Corresponding Author: E. Tarikci Kilic ORCID: 0000-0002-5377-1090

Health Sciences University Ümraniye Training and Research Hospital, Department of Anesthesiology and Reanimation, Istanbul, Turkey

ebru.tarkc@yahoo.com

R. Kahraman

ORCID: 0000-0001-5534-0860

K. Ozdil

ORCID: 0000-0003-2556-3064 Health Sciences University Ümraniye Training and Research Hospital,

Department of Gastroenterology, Istanbul, Turkey 


\section{INTRODUCTION}

Endoscopic retrograde cholangiopancreatography (ERCP) is a widely used exploratory technique for the treatment of biliary and pancreatic disorders worldwide. McCune first performed the technique in 1968, and because of the improvements in ERCP since the first sphincterotomy was performed by Kawai et al. ${ }^{1}$ in 1974 , ERCP has become the gold standard for both the diagnosis and treatment of pancreaticobiliary disorders.

The main indications for ERCP comprise recurrent and/or retained choledocholithiasis, malignant and benign strictures of the biliary ductal systems, sphincter of Oddi dysfunction, ampullary stenosis, major-minor ductal injuries, suspicion of pancreatic cancer, pancreatitis of unknown cause, and chronic pancreatitis. Additionally, ERCP has limited contraindications, such as severe coagulopathy, upper aerodigestive obstruction, esophageal and/or gastric varices, anaphylactic reaction to contrast medium, acute non-biliary pancreatitis, and severe cardiorespiratory impairment ${ }^{1}$.

Notably, ERCP causes extreme pain and discomfort. Thus, it is necessary to perform the interventions under sedation and with analgesia support to enable the endoscopist to work more easily and facilitate patient comfort.

Despite the fact that ERCP is invasive and involves the risk of potential complications associated with anesthesia or the procedure itself, it is widely considered to be safe, with the benefit of obviating the need for surgery in patients with poor performance. The patients undergoing this procedure are usually hospitalized because of their frail general condition. Complications such as hypertension, hypotension, bradycardia, oxygen desaturation, abdominal discomfort, dizziness, and minor and major bleeding can be encountered during the procedure. For this reason, ERCP should be closely monitored with appropriate methods $\mathrm{s}^{2,3}$. In this retrospective data-based study, we aimed to evaluate the clinical and demographic features as well as the outcomes and complications of patients who underwent ERCP under sedation between January 2014 and January 2018 at our endoscopy department.

\section{MATERIALS and METHODS}

This study was approved by the Health Sciences University, Umraniye Training and Research Hospital Ethic Committee for Clinical Studies (23 April 2018, 2018/49).

All patients who underwent ERCP procedures in the Endoscopy Unit of the Department of Gastroenterology between January 2014 and January 2018 were included in the study, and their data and clinical records were retrospectively evaluated.

Patients in whom stents had been withdrawn were excluded from the study. Aside from the demographic data, indications, comorbidities, type of anesthesia, number of procedures, American Society of Anesthesiologists (ASA) risk status, and acute physiology and chronic health evaluation (APACHE2) scores of the patients, procedural and post-procedural complications, early admission and admission to the intensive care unit, and 30day mortality rates were also investigated in detail.

Initially, all patients were taken to the endoscopy unit after a 6-hour fasting period. Next, intravenous access was established, and fluid infusion was initiated. Simultaneously, cardiac apex beat, blood pressure, peripheral oxygen saturation, and depth of anesthesia were monitored using the bispectral index (BIS). All patients received oxygen via a nasal cannula. Although premedication was not administered before the procedure, midazolam $(0.03 \mathrm{mg} / \mathrm{kg} \mathrm{IV})$ and ketamine $(1 \mathrm{mg} / \mathrm{kg}$ IV) were administered to induce deep sedation, and propofol infusion was titrated and maintained at BIS $60-80$ to maintain the sedation at a certain level throughout the procedure. All ERCP procedures were performed by experienced gastroen- 
terologists with 10 or more years' experience in this specific procedure.

Cannulation with the aid of a guidewire for insertion of a catheter into bile duct and standard duodenoscopes were performed. However, sphincterotomes were used in most cases. For stone removal, a basket, balloon catheter, or mechanical lithotripter were used as per convention. A mechanical lithotripter was used to crush stones that were too large to remove. Further, complete removal of stone(s) from inside the common bile duct was attempted at each procedure. Complete stone removal was confirmed by cholangiography. In cases where stone removal was not achieved completely, a 7.0-10Fr tube was placed depending on the endoscopist's preference. Successful ERCP was defined as the procedure completion rate. Following the completion of ERCP as a preventive measure to avoid pancreatitis, adequate rehydration was performed in all the cases. Finally, the patients received intravenous diclofenac $50 \mathrm{mg}$ for pain control.

\section{Statistical Analysis}

The Number Cruncher Statistical System (NCSS) 2007 program (Kaysville, Utah, USA) was used for statistical analysis. In addition to descriptive statistical methods (mean, standard deviation, median, frequency, rate, minimum, and maximum), the Student t-test was used to compare quantitative variables with normal distribution between the two groups, and the Mann-Whitney $U$ test was used to compare variables without normal distribution. Pearson's chi-square test, Fisher-FreemanHalton test, and Fisher's exact test were used in the comparison of qualitative data. P values $<0.05$ were considered statistically significant.

\section{RESULTS}

The study assessed 1337 patients treated at the gastroenterology clinic between January 2014 and January 2018. Demographic parameters were presented in Table 1. The ASA scores were grouped between classes I-II (low intraoperative risk) and III-IV (moderate-to-high risk). The patients who received treatment were in risk groups of ASA I-II (71.73\%) and ASA III-IV (28.27\%) (Table 1).

Table 1. Demographic parameters of the patients.

\begin{tabular}{lll}
\hline Demographic & Characteristics & n (\%) \\
\hline Age (years) & $\begin{array}{l}\text { Min-Max } \\
\text { (Median) }\end{array}$ & $18-104(62)$ \\
& $\begin{array}{l}\text { Mean } \pm \text { SD } \\
\text { 18-65 years old }\end{array}$ & $60.58 \pm 17.96$ \\
& 65-75 years old & $274(20.49)$ \\
& 75-85 years old & $258(19.30)$ \\
& $>85$ years old & $72(5.39)$ \\
Gender(F/M) & Female & $775(57.96)$ \\
BMI $\left(\mathrm{kg} / \mathrm{m}^{2}\right)$ & Male & $562(42.04)$ \\
& Min-Max & $16.7-39.1(27)$ \\
ASA scores & Mean \pm SD & $26.79 \pm 3.36$ \\
I & & $601(44.95)$ \\
II & & $358(26.78)$ \\
III & & $178(13.31)$ \\
IV & & $200(14.96)$ \\
\hline
\end{tabular}

Indications, procedure types, number of applications, and complication rates are shown in Table 2. Cannulation was unsuccessful in $2.55 \%$ of the patients $(n=34)$ due to altered surgical anatomy (14/34) and multiple large diverticula (20/34).

Table 2. Distribution of indication, procedure and complication characteristics.

\begin{tabular}{lll}
\hline $\begin{array}{l}\text { Indication, Procedure and Complication } \\
\text { Characteristics }\end{array}$ & n (\%) \\
\hline Indications & Choledochal stone & $875(65.45)$ \\
& Cholangitis & $188(14.06)$ \\
& Malignancy & $98(7.33)$ \\
& Pancreatitis & $92(6.88)$ \\
& Other & $84(6.28)$ \\
Type of procedure & ERCP & $1318(98.58)$ \\
& ERCP+EUS & $19(1.42)$ \\
Number of procedures & Min-Max (Median) & $1-9(1)$ \\
& Mean \pm SD & $1.37 \pm 0.85$ \\
& 1 & $986(73.75)$ \\
& 2 & $241(18.03)$ \\
& $\geq 3$ & $110(8.22)$ \\
Minor+Major complications & No & $1207(90.27)$ \\
& Yes & $96(7.18)$ \\
Unsuccessful sphincterotomy & $34(2.55)$ \\
& Yes & $6(0.45)$ \\
Major complication (n=6) & Exitus (in hospital) & $4(0.29)$
\end{tabular}

- There are cases with multiple indications. 
E. Tarıkcı Kılıc et al. Evaluation of Safety and Outcomes of Endoscopic Retrograde Cholangiopancreatography in 1337 Patients at a Single Center

Anesthesia-related transient adverse events were observed in 274 patients aged 65-75 years including arrhythmias $(n=14)$, transient respiratory depression $(n=42)$, and apnea $(n=12)$, and the procedure was continued and completed with medical treatment. Among 258 patients aged 7585 years, 33 had atrial fibrillation with rapid ventricular rhythm. The procedure was ceased in three cases, whereas ventricular rhythm was regulated by medical treatment in the remaining cases, and then the procedure was completed. Among 72 patients aged $>85$ years, hypotension and desaturation were observed in 15 patients. Moreover, the procedure was ceased in three cases, whereas the remaining procedures were continued and completed with the aid of medical treatment (Fig 1).

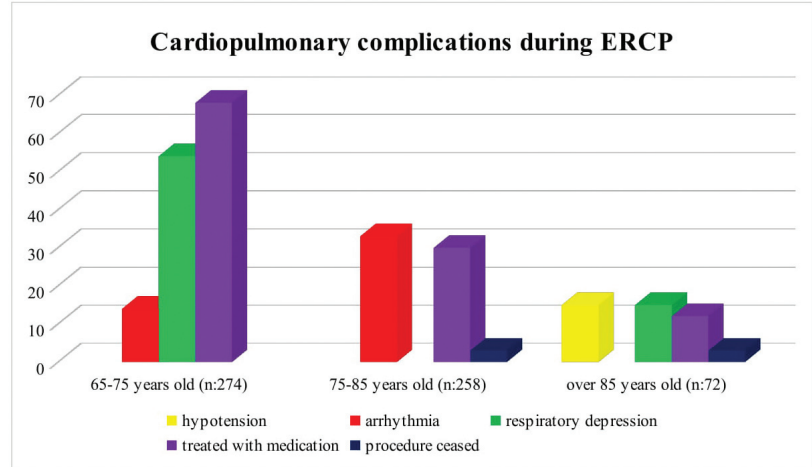

Figure 1. Cardiopulmonary complications during ERCP.

Comorbid diseases were detected in $64.17 \%$ of the patients ( $n=858$ ) (Fig 2). Distribution of comorbid diseases are given in Table 3.

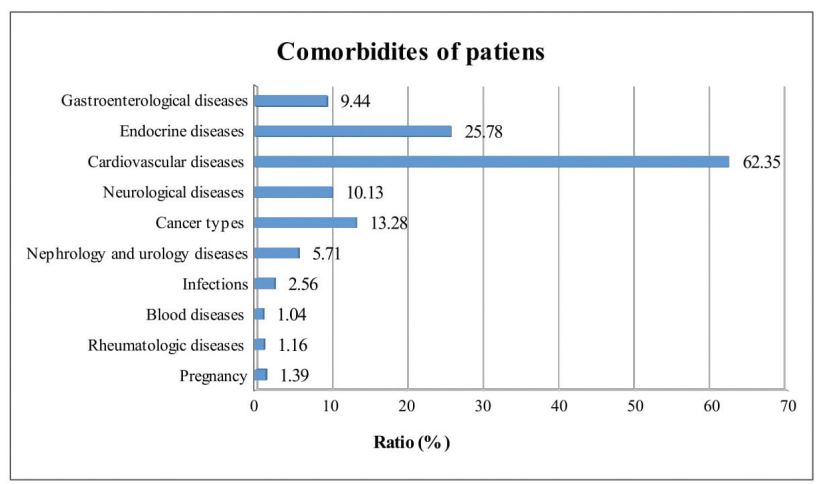

Figure 2. Comorbidity of patients.
Table 3. Distribution of comorbid diseases.

\begin{tabular}{lll}
\hline Comorbid Disease Characteristics & n (\%) \\
\hline $\begin{array}{l}\text { Comorbid disease } \\
\text { presence }(\mathrm{n}=1337)\end{array}$ & $858(64.17)$ \\
$\begin{array}{l}\text { Type of comorbid } \\
\text { disease }(\mathrm{n}=858)\end{array}$ & $\begin{array}{l}\text { Gastroenterological } \\
\text { diseases }\end{array}$ & $81(9.44)$ \\
& $\begin{array}{l}\text { Endocrine diseases } \\
\text { Cardiovascular diseases }\end{array}$ & $222(25.87)$ \\
& $\begin{array}{l}\text { Neurological diseases } \\
\text { Various Types of Cancer }\end{array}$ & $114(10.13)$ \\
& $\begin{array}{l}\text { Nephrological and } \\
\text { urologic diseases }\end{array}$ & $49(5.71)$ \\
& Infections & $22(2.56)$ \\
& Blood diseases & $9(1.04)$ \\
& $\begin{array}{l}\text { Rheumatologic diseases } \\
\text { Pregnancy }\end{array}$ & $10(1.16)$ \\
& & $12(1.39)$ \\
\hline
\end{tabular}

-There are cases with multiple comorbid diseases.

Forty-four patients (3.29\%) were admitted into the intensive care unit. Their APACHE 2 scores ranged between 1 and 44 points (mean score: $10.37 \pm 10.76$ points). Procedure-related mortality rate was $0.29 \%(n=4)$. Three patients died because of perforation in the intensive care unit within 2 days. Four patients with the highest APACHE scores died because of cardiovascular comorbidity (Table 4).

Table 4. Admission to intensive care unit, APACHE 2 scores and mortality distributions after ERCP.

\begin{tabular}{|c|c|c|}
\hline \multicolumn{2}{|l|}{ Hospitalization and Outcomes } & \multirow{2}{*}{$\begin{array}{l}\text { n (\%) } \\
44(3.29)\end{array}$} \\
\hline Intensive Care Hospitalization & & \\
\hline APACHE 2 & $\begin{array}{l}\text { Min-Max } \\
\text { (Median) }\end{array}$ & $1-40(4)$ \\
\hline & Mean \pm SD & $10.37 \pm 10.76$ \\
\hline Mortality related ERCP & Alive & $1333(99.71)$ \\
\hline & Ex & $4(0.29)$ \\
\hline Mortality (30 days) $(\mathrm{n}=22)$ & $\begin{array}{l}\text { Min-Max } \\
\text { (Median) }\end{array}$ & $0.1-30(6)$ \\
\hline & Mean \pm SD & $3.99 \pm 1.22$ \\
\hline
\end{tabular}

Among 1337 patients treated with ERCP, postERCP pancreatitis was observed in 54 (4.03\%), minor bleedings in 28 (2.09\%), and major bleeding treated with blood transfusion was detected in $2(0.15 \%)$ patients, mostly resulting from aspirin usage Of the 733 patients in the younger group (age, 18-65 years), we did not observe any anesthesia-or procedure-related adverse events (0\%) (Table 5). 
Table 5. Distribution of complications.

\begin{tabular}{|c|c|c|c|c|}
\hline Complications & $\begin{array}{l}\text { Age } \\
65-75\end{array}$ & $\begin{array}{l}\text { Age } \\
75-85\end{array}$ & $\begin{array}{l}\text { Age } \\
>85\end{array}$ & Totally (\%) \\
\hline Cholangitis & 3 & 4 & 1 & $8(0.59)$ \\
\hline Cardiopulmonaryarrest & 1 & & & $1(0.07)$ \\
\hline Bleeding (minor) & 19 & 5 & 4 & $28(2.09)$ \\
\hline Bleeding (major) & 2 & & & $2(0.15)$ \\
\hline Acutepancreatitis & 29 & 24 & 1 & $54(4.03)$ \\
\hline Perforation & 2 & 1 & & $3(0.22)$ \\
\hline
\end{tabular}

The 30-day mortality rate was $1.64 \%(n=22)$ (Table 4 ). There was a statistically significant difference in mean age between survivors and nonsurvivors, and the mean age of non-survivors was found to be higher $(\mathrm{P}<0.01)$. Similarly, there was a significant difference in mortality rates according to gender $(P<0.01)$, and the mortality rate in males was higher than in females.

A significant difference was found in mortality rates according to the presence of malignancy, with the mortality rate being significantly higher in patients with malignancy than in those with benign diseases $(100 \%)(\mathrm{P}<0.01)$.

Additionally, a significant difference was found in mortality rates according to admission into the intensive care unit. The mortality rate was higher among patients who were admitted to the intensive care unit with significantly higher APACHE 2 scores than patients with lower APACHE 2 scores $(\mathrm{P}<0.01)$.

\section{DISCUSSION}

As mentioned above, success rates of ERCP were found to be high. Our analysis showed that there was no complication in $90.27 \%$ of the cases and the procedure-related mortality rate was 0.29\%. Thus, these statistics support the use of ERCP because of its low rates of adverse events.

Many studies have been performed to evaluate ERCP outcomes in terms of success rates and complications. In 2019, Mariani et al. ${ }^{4}$ reported a total of 2388 cases of ERCP, in which biliary cannulation was achieved in 2293 cases. They reported a success rate of $91.1 \%$ and concluded that ERCP can be safely performed by skilled endoscopists.

Sugiyama $M$. et al. ${ }^{5}$ retrospectively investigated the early and long-term outcomes of ERCP in patients aged $<60$ years. They reported that early complications occurred in $7.8 \%$ and late complications developed in 10 out of 110 patients. They concluded that ERCP is safe and effective.

ERCP is a less invasive procedure used for the treatment of various pancreaticobiliary disorders and has lower mortality and morbidity than surgical procedures. The principle that "endoscopy should be performed if it will change the treatment and clinical course," which is applicable to all age groups, should be strictly followed for ERCP procedures, particularly in the elderly population $^{6}$. Furthermore, the mortality rate following surgical treatment in the elderly group is $20 \%{ }^{7}$. For this reason, ERCP is preferred in this age group because it is a less invasive alternative.

In the literature, the ERCP success rate in the geriatric patient group is no lower than that in the younger age group. Thus, $88 \%-100 \%$ of all patients can be successfully treated with ERCP ${ }^{8,9}$. In elderly patients, ERCP is more successful than surgery in the palliative treatment of biliopancreatic diseases with lower morbidity and mortality rates. In a series comparing ERCP and surgery for the palliative treatment of patients with malignant stricture of the bile duct, mortality and morbidity rates were found to be $3 \%$ and $11 \%$ vs. $14 \%$ and $29 \%$, respectively ${ }^{10}$. ERCP also reduces the need for surgery in geriatric patients ${ }^{11}$.

Finkelmeier et al. ${ }^{12}$ found that anesthesia and procedural complications were more frequent in patients aged $>80$ years. This finding was supported by Anderson ${ }^{13}$, who concluded that cardiac complications were higher in patients with advanced age. When age groups were examined in our study, anesthesia-related complications were also 
more common in patients aged $>75$ years. Hence, the procedures were ceased in six patients aged $>75$ years, but these procedures were completed in the second or third session.

Considering that ERCP causes pain and discomfort and leads to fear and anxiety, it is performed with moderate sedation that is in a state of somnolence, in which there is spontaneous breathing but no response to verbal stimuli. Notably, elderly patients exhibit an increased response to sedative agents. Because of a decrease in vital capacity and vascular elasticity, such patients tend to have hypotension, hypoxia, and arrhythmia. Cardiorespiratory and respiratory responses are delayed, and episodes of temporary apnea occur. The risk of hypothermia and aspiration is high ${ }^{11,12}$.

In a 3-year retrospective study by Galeazzi et al. ${ }^{14}$, the success rate was $92.8 \%$ in patients aged $65-$ 80 years and $93.5 \%$ in patients aged $>80$ years. Moreover, the ERCP-related complication rate was $10 \%$ in patients aged $>80$ years and $13.2 \%$ in patients aged $<80$ years. They emphasized that the number of ERCP procedures will also increase as average life expectancy increases. In this study, we found approximately the same complication rates for this age group.

According to a study by the World Health Organization, it is estimated that the population of individuals over 100 years old will rise from 310.000 in 2011 to $3.200,000$ in 2050 . In other words, ERCP is an noninvasive procedure, incidence rates of pancreaticobiliary disease in aging population, and accordingly number of ERCP procedures performed will naturally increase compared with surgery ${ }^{15}$.

In our study, 99\% of the patients were discharged after stone extraction and stenting. We believe that a well-controlled sedation with BIS followup is quite safe with cholangitis-related sepsis and is also very reliable in terms of maintaining the continuity of the procedure. Randomized tri- als emphasizing the importance of early ERCP in sepsis have been conducted. Neoptolemos et al. ${ }^{16}$ performed ERCP for 121 randomized patients with acute biliary pancreatitis within 72 hrs and administered medical therapy to the other group. A reduction in mortality and morbidity rates was observed in patients with a Glasgow Coma Score of $\geq 3$. Furthermore, Fan et al. ${ }^{17}$ performed ERCP for 127 patients with acute biliary pancreatitis and found a decrease in rates of mortality caused by biliary sepsis in patients who underwent early ERCP.

Several centers generally report the incidence rates of ERCP-related complications as 0.7\%-40\% and those of ERCP-related mortality as $0.4 \%$. In Turkey, the ERCP-related complication rate was $7.2 \%$ in a single-center study by Sarıtaş et al. ${ }^{18}$, in which all procedures were performed by the same endoscopist. In agreement with these study findings, the overall complication, and mortality rates in our study were $7.18 \%$ and $0.29 \%$, respectively.

With the increase in the incidence of pancreatobiliary disorders, we are performing greater number of ERCP procedures. Complications such as arterial hypoxia, arrhythmia, aspiration, apnea, and myocardial ischemia can occur. Additionally, sedative agents used at our center (midazolam, ketamine, and propofol) result in less hypoxia and hypotension. BIS-controlled ketofol anesthesia is safer because it provides rapid recovery. There are no universally accepted comfort and sedation scoring systems, but we observed a more suitable sedation profile at our clinic when ketofol was used for the induction and maintenance of anesthesia.

Among all procedures in our study, the 30-day mortality score was $1.64 \%$. Chatterjee et al. ${ }^{19}$ reported an overall complication rate of $5 \%$, which is similar to ours, and the 30-day mortality rate was $2 \%$ (10 patients) among all the procedures performed in their study. Four patients died of 
progressive malignancy. The other six deaths were related to underlying medical conditions, and there were no deaths directly related to the ERCP procedure itself, such as bleeding, perforation, or pancreatitis. The mortality rate and the risk of complications were very similar to those found in the present study.

A major conclusion of our study was that in the very young population (age, 18-30 years), the most common indications of ERCP were cholangitis and gallstone pancreatitis. Additionally, no adverse events were noted during the procedure or within 30 postprocedural days.

There are several limitations to our study. This was a retrospective analysis conducted at a single tertiary center, and the results cannot be generalized to all centers. Our study also lacks longitudinal follow-up, so the proportion of patients who had further biliary complications is not known.

\section{CONCLUSION}

The present study demonstrated that the overall rate of adverse events associated with ERCP was low, with a high clinical success rate. The most important method to reduce complications is to identify the appropriate indications for ERCP and predict the complications that may develop by taking patient risks into account in an interdisciplinary setting. In our view, with careful attention to detail, ERCP is safe and lifesaving.

\section{Acknowledgements:}

We thank to the professional staff of gastroenterology department for their assistance.

\section{REFERENCES}

1. ASGE Guidelines: The role of ERCP in disease of of the biliary tract and the pancreas. Gastrointest Endosc. 2005;62:1-8. [CrossRef]

2. Raymondos K, Panning B, Bachem I, Manns MP, Piepenbrock S, Meier PN. Evaluation of endoscopic retrograde cholangiopancreatography under conscious sedation and general anesthesia. Endoscopy. 2002;34:721-6. [CrossRef]

3. ASGE Standarts of Practise Committee. Sedation and monitoring of patients undergoing gastrointestinal endoscopic procedures. Gastrointestinal endoscopic procedures. GastrointestEndosc. 1995;42:626-9. [CrossRef]

4. Mariani A, Segato S, Anderloni A, et al. Prospective evaluation of ERCP performance in an Italian regional database study. Dig Liver Dig. 2019 Jan 17. pii: S1590-8658(19)30002-7. [CrossRef]

5. Sugiyama M, Abmi Y. Follow up more than 10 years after endoscopic sphincterotomy for choledocholithiasis in young patients. Br J Surg. 1998;85:917-21. [CrossRef]

6. Cohen SA, Kasmin FE, Siegel JH. Do not desert me in my old age. Gastrointest Endosc. 2006;64:906-7. [CrossRef]

7. Beaton HL. Surgical considerations. In: Gelb Aed. Clinical gastroenterology in the elderly. New York: Marcel Dekker. 1996 p.271-82.

8. Sugiyama M, Atomi Y. Endoscopic sphincterotomy for bile duct Stones in patients 90 years of age and older. Gastrointest Endosc. 2000;52:187-91. [CrossRef]

9. Deans GT, Sedman P, Martin DF, et al. Are complications of endoscopic sphincteretomy age related? Gut. 1997;41:545-8. [CrossRef]

10. Vandervoort J, Soetikno RM, ThamTC, et al. Risk factors for complications after performance of ERCP. Gastrointest Endosc. 2002;56:652-6. [CrossRef]

11. Silveria ML, Seamon MJ, Porshinsky B, et al. Complication related to Endoscopic Retrograde Cholangiopancreatography: A comprehensive clinical review. J Gastrointestin Liver Dis. 2009; 18:73-82.

12. Finkelmeier F, Tal A, Ajouaou M, et al. ERCP in elderly patients: Increased risk of sedation adverse events but low frequency of Post ERCP pancreatitis. Gastrointest Endosc. 2015;82:1051-9. [CrossRef]

13. Anderson MA, Fisher L, Jain R, et al. Complications of ERCP. Gastrointest. Endosc. 2012;75(3);467-78. [CrossRef]

14. Galeazzi M, Mazzola P, Valcarcel B, et al. Endoscopic retrograde cholangiopancreatography in the elderly: results of a retrospective study and a geriatricians' point of view. BMC Gastroenterol. 2018;18:38. [CrossRef]

15. Coelho-Prabhu N, Shah ND, Van Houten H, Kamath PS, Baron $\mathrm{TH}$. Endoscopic retrograde cholangiopancreatography: Utilisation and outcomes in a 10-year population-based cohort. BMJ Open. 2013;3. pii: e002689. [CrossRef]

16. Neoptolemos JP, Carr-Locke DL, London NJ, Bailey IA, James D, Fossard DP. Controlled trial of urgent endoscopic retrograde cholangiopancreatography and endoscopic spincteretomy versus conservative management for acute pancreatitis due to gallstones. Lancet. 1988;2(8618):979-83. [CrossRef]

17. Fan ST, Lai EC, Mok FP, Lo CM, Zheng SS, Wong J. Early treatment of acute biliary pancreatitis by endoscopic papillotomy. New Engl J Med. 1993;328:228-32. [CrossRef]

18. SarıtaşÜ, Gören İ, Şenol A. TerapotikERCPkomplikasyonları için risk faktörleri: Tekmerkezl iprospektifçalışma. Akademik Gastroenteroloji Dergisi. 2006;5:163-8.

19. Chatterjee S, Rees C, Dwarakanath AD, et al. Endoscopic retrograde cholangio-pancreatography practice in district general hospitals in North East England: a Northern Regional Endoscopy Group (NREG) study. J R Coll Physicians Edinb. 2011;41:109-13. [CrossRef] 